\title{
Technology-Based Service Encounter-A Study of the Use of E-Mail as a Booking Tool in Hotels
}

\author{
Aihie Osarenkhoe ${ }^{1}$, Jotham Mbiito Byarugaba², Mabel Komunda Birungi², \\ Abednego Feehi Okoe ${ }^{3}$, Az-Eddine Bennani4 \\ ${ }^{1}$ Department of Business \& Economic Studies, Faculty of Education \& Economics, \\ University of Gävle, Gävle, Sweden \\ ${ }^{2}$ Makerere University Business School, Kampala, Uganda \\ ${ }^{3}$ University of Professional Studies, Legon-Accra, Ghana \\ ${ }^{4}$ Department of Management \& Strategy, Reims Management School, Reims Cedex, France \\ Email: aoh@hig.se
}

Received 4 October 2014; revised 1 November 2014; accepted 25 November 2014

Copyright (C) 2014 by authors and Scientific Research Publishing Inc.

This work is licensed under the Creative Commons Attribution International License (CC BY). http://creativecommons.org/licenses/by/4.0/

(c) (7) Open Access

\begin{abstract}
Highlighted in this paper, is the extent to which a technological interface that enables customers to produce a service outcome, independent of direct service-employee involvement, is used by hotels of various categories in France. Extant literature has, to date, devoted more attention to the use of interpersonal buyer-seller interactions in the process of creating service outcomes. This paper aims to fill this void by contributing to existing knowledge on customer interactions with technologybased self-service delivery options. An exhaustive sample of 240 hotels located across 120 cities in France constituted the empirical setting. A one-way ANOVA that tested differences between means was used to assess the impact of hotel category (independent variable) on response time (dependent variable) among hotels in France. The findings show that there is significant dissimilarity in responsiveness across the hotel categories. A major implication of these findings for management is that the speed with which enquiries from current and potential customers are responded to is most likely a prelude to providing good quality technology-based buyer-seller interactions to create positive service outcomes using the Internet/e-mail. Major concepts in customer relationship management include the response speed of firms to questions and problems during the service encounter. The main contribution of this study is that it builds on existing literature on interpersonal and technological interfaces.
\end{abstract}

\section{Keywords}

Hospitality Industry, Leisure and Pleasure Industry, Technology-Based Self-Service Encounter, 


\section{Information and Communication Technology (ICT)}

\section{Introduction}

Numerous authors [1] [2] underline that the main empirical contributions to the problem of performance have focused mainly on the industrial sector, and subsequently on certain segments in the service sector (banks, retail, insurance). Unfortunately, comparatively little attention has been devoted to the hospitality industry. However, from the 1990s onwards, many studies have applied the performance factors to the hotel sector [3]. For example, Bitner, et al. [4], Parasuraman, et al. [5] and Osarenkhoe and Bennani [6] highlight the vital role that technology plays in the delivery of services and how it will continue to be a crucial component in customer-firm interactions. These technology-based interactions are expected to become a key criterion for long-term business success [7].

As noted above, there has been unprecedented resurgence of academic as well as practitioner interest in the salient features and dynamics of interpersonal interactions between service providers and customers [9]-[19]. Customer interactions with technological interfaces in hospitality sector, on the other hand, are under researched [4]. Despite the proliferation of customer relationship management enabled technology (self-service technologies, telephone banking, automated hotel checkout, and online investment trading whereby customers produce services for themselves without the assistance of firm employees) firms are increasingly aware that there are barriers to customer adoption and substantial implementation obstacles to be overcome. Some features of hotel businesses and, in particular the presence of three different business areas marked by high intangibility (rooms), the presence of a physical asset (food and beverage) and the typical features of a retail business (shops), coupled with the strong growth recorded by the sector in the past, growing competition and the existence of a high spatial concentration (destinations), make this industry a unique and fascinating research field [20]-[23].

This paper therefore addresses issues regarding the impact that the increasing use of information and communication technology (ICT) in general and electronic means of interaction (a technological interface that enables customers to produce a service independent of direct service employee involvement) in particular has on the process of creating value and the differentiation in service activities in the hospitality industry. The globalization of markets and production has enhanced the propensity of the actors operating in the hospitality business sector to adopt e-mail technology that enables their guests to book and/or to pay for a stay, thus bypassing travel agencies. Still there are large variations in the use of this interface across hotels categories [16]. There can be significant dissimilarities in the response time when using e-mail to communicate with customers.

This paper studies these dissimilarities on the basis of an e-mailing action that encompasses sending a typical room-booking request to French hotels. It analyzes the response time to see how promptly hoteliers reply, and which hotel categories — one-star, two-star, three-star or four-star hotels-use e-mail to answer their customers rapidly. The objective here is to draw up an overview of e-mail as used by hotels in France and to work out whether the response time differs across hotel categories. We begin with an introduction to the theoretical framework in the form of a review of the literature related to the use of ICT and the Internet in the hotel industry. This is followed by a description of the research methodology, a presentation and analysis of the findings, before drawing our conclusions, in addition to the study's contribution to extant literature on the technology-based service encounter.

\section{Theoretical Background and Hypothesis}

\subsection{Technology-Based Service Encounter}

The world is becoming increasingly characterized by technology-facilitated transactions [9] [16]. Growing numbers of customers interact with technology to create service outcomes instead of interacting with a service firm employee [7] [15]. According to Tosun [24], the characteristics of the firm and industry sector are, however, contributory factors to the extent of adoption and exploitation of information and communication technology by firms to support business processes. The use of ICT has been growing fast in the worldwide hospitality industry. Hoteliers are increasingly adopting the Internet, mainly e-mail and websites, to interact with their guests and provide easier access to customized services.

Buyer-seller interactions during the service encounter have historically taken place on an interpersonal basis 
[9]-[17]. Recent research has recognized the critical importance of technology in the delivering of services [4] [5] [7] [25]-[27]. In this scenario, the tourism industry might increase the chances of success by exploiting the potentialities of these technologies along with new business practices and strategies. To date, several projects in ubiquitous and context-aware computing have been focused on mobile devices (i.e. iPhone, iPod, iPad, pocket PC, etc.) as support for museum and tourism guides [28] [29] in order to retain existing tourists and attract new ones. One of the most efficient tools might be represented by pervasive environments, which have not been thoroughly investigated in the tourism literature.

The increasing competition between regions is forcing the tourism industry to define new strategies in order to improve the position of each area, thus attracting greater tourism flows [30] [31] and enhancing economic advantages [32] [33]. Current research in information and communication technology has a considerable effect on the tourism sector, by providing innovative tools capable, on one hand, of supporting consumers in organizing their holidays and, on the other one, of supplying fast and efficient information on consumer behavior. These innovations compel the sector to develop new marketing and managerial strategies [34]. For instance, according to Chu et al. [35], from 1990 to 2000, new websites have been developed, improving the quality of user interaction. In the beginning, Websites were utilized to deliver tourism information such as advertising aimed at promoting tourism attractions.

\subsection{The Use and Impact of ICT in the Hospitality Industry}

According to DiPietro and Wang [36], the lodging industry has, historically, distributed information through print-based media such as brochures, travel planners, or regional guides, and received reservations by mail, phone, and fax. More recently, hotel rooms have been made accessible for booking through global distribution systems (GDS) and through direct access to hotels using central reservation systems (CRS). However, such technologies have been inadequate as customers have traditionally not had access to these systems and travel intermediaries have experienced difficulty and delay in finding and booking appropriate hotels, whereas hotels have incurred high administrative costs to attract and process customer bookings. The emergence of new ICT interfaces presents new opportunities to make these processes more accessible and more efficient [37]. Some suggest that the traditional marketplace interaction is being replaced by a "marketspace" transaction [4] [8]. In this context, e-mail technology is an example of marketspace interactions in which no interpersonal contact is required between the buyer and seller.

E-mail offers a promising tool to help marketers keep in touch with their customers on a regular basis at low cost [14] [38]. The benefits of an active marketer are described in considerable detail in the customer relationship management (CRM) literature, suggesting that marketers can enhance customer loyalty by being active and in regular contact with their customers (see Hansotia [39] and Osarenkhoe and Bennani [13]). In spite of these potential roles for e-mail marketing in building and maintaining customer loyalty, it has only recently started to gain importance in comparative marketing literature and CRM strategies. This is also noted by Reichheld and Schefter [40] (cited in [38]), who discuss how marketers should concentrate efforts on retailing rather than attracting customers on the Internet.

A methodology for assessing ICT productivity impact proposed by Sigala [41] and tested on a dataset of three-star hotels in the UK overcomes these shortcomings. Sigala's findings reveal that productivity gains do not accrue from ICT investments per se, but rather from the full exploitation of its networking capabilities. Martin's [42] study of e-innovation and Internet impacts on UK hospitality firms looks at six cases in the hospitality sector. Martin's study suggests that the current narrow focus on business growth or on technology alone seen in current initiatives may overlook owners such as those who established an online presence for social and personal purposes but developed business uses alongside these purposes. Where targets are set for increased tourism, Martin notes that the Internet could play a part in developing such growth, if integrated and applied to the context of hospitality firms. Collins et al.'s study [43], on the other hand, of a tourist enterprise in the European hotel sector and its utilization of the Internet and perception of online learning systems, aim to demonstrate that ICTs can enable firms to improve their inventory management, strengthen their marketing and communication strategies, and develop their internal business processes. Their survey [44] demonstrates that small and mediumsized tourist firms in the European hotel sector are not utilizing ICT in their businesses to its full potential. These businesses primarily see the Internet as a mechanism for promoting their hotels rather than for inter- and/ or intra-organizational- and e-commerce purposes. 
It can be deduced from the preceding discussion that ICT improves the quality of customer-oriented, personalized service, allows the delivery of e-service, and enhances customer relationships [45]. Some questions, such as the relationship between the client and the supplier, emerge due to the integration of the Internet in company strategies. Because of the use of websites and e-mail, some researchers have reservations about the lack of physical and direct contact between the service provider and his/her customer [46]. This challenges the traditional way of doing business, where customers are served either face to face and/or over the telephone. It allows oneto-one interaction, offers electronic services to customers [40], and makes online relationships possible.

\subsection{How the Internet Helps the Hotel Industry}

The rapid advancement of technology affects practically every industry, and the hotel and service industry is not exempt from this [27] [47]. Previous studies show, in addition, that the firms that provide electronic data interchange (EDI, an electronic communication system that provides standards for exchanging data via any electronic means) offer more services to their customers than firms that do not provide EDI service [5] [48]-[50]. With global and local hotel brands turning to the World Wide Web in order to boost sales and facilitate customer relations, it is easy to see how the industry is evolving along with the Internet [24] [28]. Social networking sites, led by the Facebook phenomenon, are proving to be more and more important for not only hotels but for other businesses as well [32] [34]. With the prevalence and influence of user-generated content such as reviews and other forms of feedback, hotels get the benefit of plugging by way of word-of-mouth [51]. Maintaining relationships with previous clients also becomes easier to handle with a variety of online tools at the hotels' disposal [51] [52]. There are also websites dedicated to bringing travel services and accommodations straight to the consumers' monitors whether it is through standard personal computer access or through the exponentially growing number of mobile phone Internet users [47] [53]. There are also other utility websites that aid consumers by providing aggregate information, reviews and feedback from numerous sources [52]. Just how big is the impact of online booking for the hotel industry?

According to Van Hoof et al. [54], ICT is a major opportunity for the lodging industry, particularly when it comes to marketing and selling room nights. Internet can increase the interaction phenomenon between suppliers and their customers [55]-[57]. As an effective medium for the relationship between guests and hoteliers, it can improve pre- and after-sales service and enhance customer relationships [45] [58]. Its potential as a means of making reservations is remarkable [9] [51]. More and more people make reservations online and travel seems to be a typical service category sold on the Internet. In the USA, as well as in the European Union, travel services seem to be the most purchased item on the Web. To enhance these key success factors in the hotel industry, some authors believe that hoteliers should invest heavily in more technology focusing on guest services [59]. Kim and Kim [60] postulate that hoteliers should first focus on basic Internet tools such as e-mail. The latter is strategically important for the hospitality industry [19] [47] because, firstly, it enables marketers to experiment with various messages, altering the offer or segmentation to improve outcomes and results. Secondly, compared to conventional direct marketing reply times that can take several weeks, $80 \%$ of e-mail messages are answered within a few days [61].

ICT clearly represents the most significant competitive innovation in the hospitality industry throughout the 1990s and beyond [62]. In addition, as transactional costs continue to rise, hotels will need to determine which of the technologies used to develop reservation and distribution channels are the most profitable for them and how they can yield the best results by using these channels. Cooper et al. [63] underlined that electronic distribution channels available to hotels have increased dramatically in recent years and, while there are multiple channels, some are obviously minor in terms of their impact and potential. Therefore, selecting the appropriate distribution channels is vital for success, and important if hotel firms want to increase top-line revenues and control overhead costs. Though the range of choice facing hotel executives is vast, e-mail adds another channel that is ubiquitous, cheap, digital, and virtual. Increasing competition has pressured hoteliers into adopting the technology in US [59], Hong Kong [51], Taiwan [64], Thailand [27], Australian [54] and UK [41] luxury class hotels. Pechlaner et al. [65] found in their research that e-services are more effective in higher-rated Swiss, Austrian and Italian hotels. Hotels in France, particularly luxury class hotels, should therefore make better use of e-mailing and should provide their customers with high-quality, professional e-service. Responsiveness is the most likely first step in providing this quality e-service using the Internet/e-mail.

Hence the following hypotheses: 
H1: E-mail responsiveness is proportional to the number of stars a hotel has: the more stars, the quicker their response.

H2: The richness of the response has a significant impact on the response time.

\section{Research Methodology}

As for e-tourism, in 2012, between 5.5\% (Raffour Interactive) and 14\% (TNS Sofres) of active French Internet users purchased their travels online, whereas $14 \%-24 \%$ used the Internet to prepare their travels. According to a French Tourist Board report, the Internet has gained ground compared to the other booking channels. In 2011, the sales turnover for e-tourism in France for the online business-to-customer tourist trade was between 880 million and 1.3 billion EUR. At the end of 2012, online hotel reservations accounted for 3.6\% of the total travel market in Europe. $64 \%$ of online hotel reservations were made on hotel company websites (Accor.com but also Ryanair.com); 36\% were carried out by online intermediaries (such as Expedia and lastminute.com). Table 1 gives the breakdown of French hotels (independent voluntary and integrated chains) according to ownership category. In 2012, there were 11,642 independent hotels and 6575 local chains or multinationals. $63 \%$ of all hotels in France are independently owned and 38\% are either local chains or multinationals.

The methodological approach adopted consisted of three steps: firstly, a sample of hotels located in France were identified on the Internet. Secondly, those including .com, .fr or .net extensions in their e-mail address and those having their own domain name server $\left(\mathrm{DNS}^{1}\right)$ were browsed. Finally, the replies received within a twomonth period of time were analyzed. A population of hotels with an e-mail address on France Tourism websites was selected. The sample included 240 hotels located in France, the target group, spread out over 120 cities. Two-star hotels were predominant in the sample (Table 2), followed by hotels in the three-star category. These two categories accounted for $86 \%$ of the overall target population. Also the limited number (around $4 \%$ ) of one-star hotels was also noted. E-mails with a booking request were sent to one-, two-, three- and four-star hotels. Written in French, they asked for information about room availability and prices for two adults and two children (16 and 10 years old) for a one-week stay in July, as well as for information on local tourist attractions and excursions and their prices. The e-mails were sent to the selected hotels. The $\mathrm{Bcc}^{2}$ function enabled us to send multiple e-mails simultaneously while masking this mass mailing for recipients. E-mails that failed to be delivered due to incorrect addresses or to any other problem were not re-sent.

Table 1. France’s tourist hotel 31/12/2012 (Source: French tourist board 2013).

\begin{tabular}{ccc} 
& Independent hotels & Chains (integrated, franchised, voluntary) \\
\cline { 2 - 3 } & Number of hotels $31 / 12 / 2012$ & Number of hotels $31 / 12 / 2012$ \\
\hline $0^{*}$ & 1342 & 796 \\
$2^{*}$ & 1505 & 353 \\
$3^{*}$ & 6223 & 3644 \\
$4^{*}$ & 2248 & 1387 \\
Total & 324 & 395 \\
\hline
\end{tabular}

Table 2. Breakdown of hotel categories in the sample.

\begin{tabular}{ccccccc}
\hline Hotel Category & 1-Star & 2-Star & 3-Star & 4 -Star & Not Specified & Total Sent \\
\hline France & $4 \%$ & $62 \%$ & $24 \%$ & $6 \%$ & $4 \%$ & $100 \%$ \\
\hline
\end{tabular}

${ }^{1}$ For example, the DNS included in www.reims-ms.fr is "reims-ms". This one is the property of Reims Management School. In www.wanadoo.fr/company, the DNS is "wanadoo", which belongs to France Telecom.

${ }^{2}$ Blind carbon copy. 
E-mail replies from these hotels were followed-up over a two-month period. On a weekly basis, the received e-mails were analyzed one by one and the information included in them was entered into a database.

\section{Research Findings and Analysis}

As far as errors are concerned, globally $10 \%$ of the sent e-mails were returned as undeliverable due to a faulty address. Of the entire sample (240), 107 hotels replied to the delivered e-mails. More than one in two hotels that replied belonged to the two-star category (Table 3). This shows the domination of this class. It was also noted that the response rate for this category corresponded closely to that of the e-mails sent.

Among the replies, one-star and four-star hotels were under-represented. It was also observed that only a few hotels did not mention their category (around 4\%). 66\% of the replies received were received within a week (Table 4).

Two and three-star categories are over-represented (55\% and 31\%, respectively) while one-star (3\%) and four-star (7\%) hotels are under-represented (Table 3). An analysis of total replies in one day (36) (Table 5), shows that almost 47\% (17/36) of two-star hotels, almost 39\% (14/36) of three-star hotels, and only 5\% (2/36) of one- and four-star hotels reply in one day. Note that $71 \%$ of the hotels that respond in under 4 hours are two-star hotels (Table 4). Also only $2 \%$ of replies received within a 4-hour time period were from one-star hotels. These results show that the hypothesis that higher category hotels in France show better responsiveness than the lower category hotels is not confirmed. This hypothesis should thus be rejected even if the four-star hotel panel is under-represented in the global sample. Above all, both the two-star and (to a lesser extent) the three-star hotels appear to reply promptly to e-mails received from customers. This could be because of the acute competition within the market segment covered by these categories. The higher category hotels probably assume that their customers belong to the business segment that does not use e-mails to make reservations. Rooms are more likely to be booked by secretaries over the telephone.

Table 3. E-mail replies according to hotel category.

\begin{tabular}{ccccccc}
\hline Hotels Category & 1-Star & 2-Star & 3-Star & 4-Star & Not Specified & Total Replies \\
\hline France & $3 \%$ & $55 \%$ & $31 \%$ & $7 \%$ & $4 \%$ & $100 \%$ \\
\hline
\end{tabular}

Table 4. E-mail replies according to response time (in \%).

\begin{tabular}{|c|c|c|c|c|c|c|}
\hline & 1-Star & 2-Star & 3-Star & 4-Star & Not Specified & Replies per Time Period \\
\hline$<4$ hours & $2 \%$ & $71 \%$ & $14 \%$ & $9 \%$ & $4 \%$ & $39 \%$ \\
\hline 1 day & $6 \%$ & $46 \%$ & $39 \%$ & $6 \%$ & $3 \%$ & $30 \%$ \\
\hline 2 days & & $70 \%$ & $24 \%$ & & $6 \%$ & $15 \%$ \\
\hline 3 days & & $66 \%$ & $17 \%$ & $17 \%$ & & $5 \%$ \\
\hline 4 days & & $80 \%$ & $20 \%$ & & & $5 \%$ \\
\hline 5 days & & & & $100 \%$ & & $1 \%$ \\
\hline 6 days & & $67 \%$ & $33 \%$ & & & $3 \%$ \\
\hline 7 days & & $100 \%$ & & & & $2 \%$ \\
\hline Replies/Category & $3 \%$ & $58 \%$ & $27 \%$ & $9 \%$ & $3 \%$ & $66 \%$ \\
\hline
\end{tabular}

On the other hand, five binomial variables relating to e-mail responses were created. These variables (room availability, nature of service (half board, full board), local tourist attractions, price of the additional activities, and refer to websites) were coded yes or no and classified into one factor: response richness. The results indicate that more than $93 \%$ of hotels provided information about their availability, while only $37.4 \%$ specify the nature of service offered (half board or full board). Few hotels (29.9\%) provided a description of available activities, and $28 \%$ provided references to their own or other websites. Only five hotels provided information about the price of the extra activities. In total, almost $48 \%$ of hotels provided references to their own or other websites. 
Table 5. E-mail replies according to response time (actual number).

\begin{tabular}{lcccccc}
\hline & 1-Star & 2-Star & 3-Star & 4-Star & Not Specified & Replies per Time Period \\
\hline 1 day & 2 & 17 & 14 & 2 & 1 & 36 \\
2 days & & 12 & 4 & & 1 & 6 \\
3 days & & 4 & 1 & 1 & & 6 \\
4 days & & 5 & 1 & & & 3 \\
5 days & & & 1 & & & 2 \\
6 days & & 2 & & & 2 & 45 \\
7 days & 1 & 32 & 6 & 3 & 9 & 137 \\
\hline
\end{tabular}

One-way ANOVA testing differences between means was used to assess the impact of hotel category (independent variable) on response time (dependent variable) for hotels in France. The results of the ANOVA analysis are presented in Table 6. They indicate that no differences were found for response time. That is, hotel category does not have a significant impact on response time (the value is more than 0.05 ). However, the results in Table 7 suggest a significant impact of the response richness on response time $(p<0.05)$.

Table 6. One-way ANOVA between hotel category and response time.

\begin{tabular}{cccc}
\hline & F ratio & P prob & Significance \\
\hline Response time & 0.843 & 0.501 & Not significant \\
\hline
\end{tabular}

Table 7. One-way ANOVA between response richness and response time.

\begin{tabular}{cccc}
\hline & F ratio & P prob & Significance \\
\hline Response time & 4.168 & 0.044 & Significant \\
\hline
\end{tabular}

\section{Concluding Remarks}

This study provides insights on the use of e-mails at customer contact points in hotels in France, for which it found significant dissimilarity in responsiveness across hotel categories. However, our findings differ from the study of Swiss hotels conducted by Pechlaner et al. [65]; and Murphy et al. [46] in Switzerland. While these previous studies found that being in the high-rated category of hotels influenced technology adoption, thus e-mail usage, they also found that hotels failed to pay much attention to improving customer service. We may note the opposite result obtained for the lower categories, mainly two- and three-star hotels.

The low level of responsiveness to e-mails (an example of marketspace interactions in which no interpersonal contact is required between the buyer and seller during the process of creating the service outcome) demonstrated by hotels of higher categories included in our sample is surprising. Responsiveness is most likely the first step in providing this quality e-service using the Internet/e-mail. One of the major concepts in customer relationship management is the speed at which firms respond to questions and problems during the service encounter. One of the major concepts in customer relationship management is the speed at which firms respond to questions and problems during the service encounter [6]. The customer relationship management literature and direct marketing literature [6] [39] suggest that regular contact with customers helps marketers to enhance customer loyalty. Direct mail is used to cross- and up-sell, to increase customers purchasing frequency, and to induce customers to respond and to become involved in a dialogue [38].

The insufficient e-service that we experienced with high category hotels in France could be explained by their lack of interest in the Internet/e-mail-user market segment. This finding seems to be in line with that reported by Sahadev and Islam [27], that the factors influencing a hotel's propensity to adopt ICTs may be broadly divided into location-related and firm-related. The findings also reconcile with the idea shared in extant literature [66], that electronic intermediation tends to "impoverish" service relations, insomuch as the technological interface 
can by no means replace the wealth of human interactions on which the creation of value and differentiation of services are based. The objectives that can be expected from the use of e-mailing - a concrete outline of e-service-in the hotel industry have to be formulated in terms of good communication, fine responsiveness, high-quality information and competitiveness.

Our findings in France are probably culturally specific. Elsewhere, the use of the ICT in the lodging industry is growing exponentially, enabling hotels to reconsider the way they do business. Although the lodging sector overall has been slow to adopt ICT compared to other industry sectors [66], many hotel managers are becoming increasingly aware of the potential distribution, promotion, and interactive marketing advantages of the technology. ICT offers several advantages for hotels of all sizes [36], one of which is increased effectiveness due to cost reduction and revenue growth. Another advantage is higher quality customer relationships due to the possibility of personal contact services and dialogue with the customer. For example, customers can answer questions about their personal preferences for rooms and, based on this information, receive services at the hotel that are adapted to these preferences.

\section{Managerial Implications}

The implications of this study for business practice and research are relatively many and straightforward:

Although the importance of people in relationship building cannot be emphasized enough, according to Donaldson and O'Toole [67], technology, particularly information and communication technology, is becoming an important strategic asset for hospitality organizations to improve their organizational performance and strategic competitiveness [66] [68]. As a result, there is a growing significance of the role of technology in enhancing a hospitality organization's competitive advantage, and thus contributing to the success of the organization. In fact, ICT use in the hospitality industry has been changing at a faster rate than at any other time in history. As younger generations become more adept at the use of technology, they want to bring that into their lodging and dining experiences. The decision to adopt and use new technology or technology systems has become so important that many hospitality organizations are transforming their corporate or organization structure to include functions and positions such as taking advantage of technology.

It is now generally agreed [30] [32] [34] [35] that ICT is the single greatest force driving change in the hotel industry and will continue to have dramatic and sweeping implications on how hotels conduct business in the future. Hotels are expected to position themselves strongly on the Internet to take advantage of its distribution capabilities such as reach, content dissemination, feedback collection, interactivity, and one-to-one marketing. Current trends furthermore indicate that this greater involvement in ICT by the industry will increasingly encompass customer-centric approaches to capitalize on the cost structure and long-term potential of the Internet while at the same time differentiating products and building lasting value propositions. For many hospitality organizations, technological advances are at the vanguard of opportunity, yet they represent one of management's biggest challenges. Adopting and using new technology systems and processes entails complicated decisionmaking that requires insight and input from strong research initiatives and organizational commitment.

Social media site such as LinkedIn, Facebook and Twitter have provided us all with great tools to leverage both existing business relationships and also new business relationships. The interference and "noise" created by social media can also have a negative impact on building relationships as more and more people aim for quick or instant results. Social media platforms are merely enablers to support our off-line networking activity. Social media platforms are only one form of communication and should not be used as an excuse to abandon the use other forms of communication. It is essential to have effective strategies to develop meaningful business relationships. Such strategies have to do with what you can do for other people, rather than what others can do for you. Also, never forget about your existing relationships [28] [29] that you may have devoted a great deal of time to cultivating. It is far too easy to let existing business relationships wither and die in the pursuit of new ones.

\section{Limitations}

While the theoretical position developed fits the unique characteristics of the case studied in the industry and country settings, caution should be exercised in generalizing the results of this study beyond this context. A number of important questions warrant continued investigation beyond the evidence of this study. The major 
concerns are, in our view, that the hotel reservation systems have advanced well beyond email communications in most countries and therefore the findings from this study may not represent a significant contribution to new development/advancements in the field of e-commerce. Although, this study has certainly added new insights to the specific field of study, we are aware that the contribution is limited. Future research should investigate how the hospitality, travel and tourist industries manage customer relationships. Since customer relationship management emerged as a technology-based customer solution in the mid-1990s, the hospitality industry, and leisure and pleasure industry have until now not been given enough coverage in extant CRM research.

\section{References}

[1] Chen, C.F. (2007) Applying the Stochastic Frontier Approach to Measure Hotel Managerial Efficiency in Taiwan. Tourism Management, 28, 696-702. http://dx.doi.org/10.1016/j.tourman.2006.04.023

[2] Pan, C. (2005) Market Structure and Profitability in the International Tourist Industry. Tourism Management, 26, 845850. http://dx.doi.org/10.1016/j.tourman.2004.04.008

[3] Okumus, F. (2002) Can Hospitality Researchers Contribute to the Strategic Management Literature? International Journal of Hospitality Management, 21, 105-110. http://dx.doi.org/10.1016/S0278-4319(01)00033-0

[4] Bitner, M.J., Brown, S.W. and Meuter, M.L. (2000) Technology Infusion in Service Encounters. Journal of the Academy of Science, 28, 138-149. http://dx.doi.org/10.1177/0092070300281013

[5] Parasuraman, A., Zeithaml, V.A. and Malhotra, A. (2005) "E-S-Qual-A Multiple Item Scale for Assessing Electronic Service Quality. Journal of Marketing, 7, 213-233.

[6] Osarenkhoe, A. and Bennani, A.-Z. (2007) An Exploratory Study of Implementation of Customer Relationship Projects. Business Process Management Journal, 13, 139-164. http://dx.doi.org/10.1108/14637150710721177

[7] Meuter, M.L., Ostrom, A.L., Roundtree, R.I. and Bitner, M.J. (2000) Self-Service Technologies: Understanding Customer Satisfaction with Technology-Based Service Encounters. Journal of Marketing, 64, 50-64. http://dx.doi.org/10.1509/jmkg.64.3.50.18024

[8] Rayport, J.E. and Sviokla, J.J. (1995) Exploiting the Value Chain. Harvard Business Review, 73, 14-24.

[9] Cheng, L.C., Gibson, M.L., Carrillo, E.E. and Fitch, G. (2011) A Technology-Centric Framework for Investigating Business Operations. Industrial Management \& Data Systems, 111, 509-530. http://dx.doi.org/10.1108/02635571111133524

[10] Bettencourt, L. and Gwinner, K. (1996) Customization of the Service Experience: The Role of the Frontline Employee. International Journal of Services Industry Management, 7, 2-20. http://dx.doi.org/10.1108/09564239610113442

[11] Yüksel, F., Bramwell, B. and Yüksel, A. (2005) Centralized and Decentralized Tourism Governance in Turkey. Annals of Tourism Research, 32, 859-886. http://dx.doi.org/10.1016/j.annals.2004.09.006

[12] Vargo, S.L. and Lusch, R.F. (2004) Evolving to a New Dominant Logic for Marketing. Journal of Marketing, 68, 1-17. http://dx.doi.org/10.1509/jmkg.68.1.1.24036

[13] Osarenkhoe, A., Bennani, A. and Lhajji, D. (2006) A study of the Prerequisites for Successful Deployment and Governance of Implementation Process of Technological Innovations. Asian Journal of Information Technology, 6, 1-20.

[14] Skinner, C. (2010) Innovation in the Internet Age. Business Strategy Series, 11, 407-411. http://dx.doi.org/10.1108/17515631011093115

[15] Chaiprasit, S. and Swierczek, F.W. (2011) Competitiveness, Globalization and Technology Development in Thai Firms. Competitiveness Review, 21, 188-204. http://dx.doi.org/10.1108/10595421111117461

[16] Lee, Y.C., Chu, P.Y. and Tseng, H.L. (2011) Corporate Performance of ICT-Enabled Business Process Re-Engineering. Industrial Management \& Data Systems, 111, 735-754. http://dx.doi.org/10.1108/02635571111137287

[17] Wiengarten, F., Fynes, B., Humphreys, P.K., Chavez, R. and McKittrick, A. (2011) Assessing the Value Creation Process of E-Business along the Supply Chain. Supply Chain Management: An International Journal, 16, 207-219. http://dx.doi.org/10.1108/13598541111139035

[18] Winata, L. and Mia, L. (2005) Information Technology and the Performance Effect of Managers’ Participation in Budgeting: Evidence from the Hotel Industry. International Journal of Hospitality Management, 24, 21-39. http://dx.doi.org/10.1016/j.ijhm.2004.04.006

[19] Sainaghi, R. (2010) Hotel Performance: State of the Art. International Journal of Contemporary Hospitality Management, 22, 920-952. http://dx.doi.org/10.1108/09596111011066617

[20] Piccoli, G., Connor, P., Capaccioli, C. and Alvarez, R. (2003) Customer Relationship Management-A Driver for Change in the Structure of the US Lodging Industry. The Cornell Hotel and Restaurant Administration Quarterly, 44, 61-73. 
[21] Dredge, D. (1999) Destination Place Planning and Design. Annals of Tourism Research, 26, 772-791. http://dx.doi.org/10.1016/S0160-7383(99)00007-9

[22] Enright, M.J. and Newton, J. (2004) Tourism Destination Competitiveness: A Quantitative Approach. Tourism Management, 25, 777-788. http://dx.doi.org/10.1016/j.tourman.2004.06.008

[23] Ingram, P. and Inman, C. (1996) Institutions, Intergroup Competition, and the Evolution of Hotel Populations around Niagara Falls. Administrative Science Quarterly, 41, 629-658. http://dx.doi.org/10.2307/2393870

[24] Tosun, C. (2006) Expected Nature of Community Participation in Tourism Development. Tourism Management, 27, 493-504. http://dx.doi.org/10.1016/j.tourman.2004.12.004

[25] Parasuraman, A. (2000) Technology Readiness Index (TRI): A Multiple-Item Scale to Measure Readiness to Embrace New Technologies. Journal of Service Research, 2, 307-320. http://dx.doi.org/10.1177/109467050024001

[26] Meuter, M.L., Bitner, M.J., Ostrom, A.L. and Brown, S.W. (2005) Choosing among Alternative Service Delivery Modes: An Investigation of Customer Trial of Self-Service Technologies. Journal of Marketing, 69, 61-83. http://dx.doi.org/10.1509/jmkg.69.2.61.60759

[27] Sahadev, S. and Islam, N. (2005) Exploring the Determinants of E-Commerce Usage in the Hotel Industry in Thailand: An Empirical Study. Information Technology \& Tourism, 7, 171-180. http://dx.doi.org/10.3727/109830505774297201

[28] Pantano, E. and Tavernise, A. (2009) Learning Cultural Heritage through Information and Communication Technologies: A Case Study. International Journal of Information Communication Technologies and Human Development, 1, 68-87. http://dx.doi.org/10.4018/jicthd.2009070104

[29] Kemperman, A.D.M., Borgers, A.W.J. and Timmermans, H.J.P. (2009) Tourist Shopping Behaviour in a Historic Downtown Area. Tourism Management, 30, 208-218. http://dx.doi.org/10.1016/j.tourman.2008.06.002

[30] Dwyer, L., Edwards, D., Mistilis, N., Roman, C. and Scott, N. (2009) Destination and Enterprise Management for a Tourism Future. Toursim Management, 30, 63-74. http://dx.doi.org/10.1016/j.tourman.2008.04.002

[31] Yeoman, I., Brass, D. and McMahon-Beattie, U. (2009) Current Issue in Tourism: The Authentic Tourist. Tourism Management, 28, 1128-1138. http://dx.doi.org/10.1016/j.tourman.2006.09.012

[32] Zhang, X., Song, H. and Huang, G.Q. (2009) Tourism Supply Chain Management: A New Research Agenda. Tourism Management, 30, 345-358. http://dx.doi.org/10.1016/j.tourman.2008.12.010

[33] Bornhorst, T., Ritchie, J.R.B. and Sheehan, L. (2010) Determinants of Tourism Success for DMOs \& Destinations: An Empirical Examination of Stakeholders' Perspectives. Tourism Management, 31, 572-589. http://dx.doi.org/10.1016/j.tourman.2009.06.008

[34] Egger, R. and Buhalis D. (2008) eTourism Case Studies: Management \& Marketing Issues in eTourism. ButterworthHeinemann, Oxford.

[35] Chu, S.C., Leung, L.C., Hui, Y.V. and Cheung, W. (2007) Evolution of E-Commerce Web Sites: A Conceptual Framework and a Longitudinal Study. Information \& Management, 44, 154-164. http://dx.doi.org/10.1016/j.im.2006.11.003

[36] DiPietro, R.B. and Wang, Y.R. (2010) Key Issues for ICT Applications: Impacts and Implications for Hospitality Operations. Worldwide Hospitality and Tourism Themes, 2, 49-67. http://dx.doi.org/10.1108/17554211011012595

[37] Buhalis, D. and Main, H. (2008) Information Technology in Peripheral Small and Medium Hospitality Enterprises: Strategic Analysis and Critical Factors. International Journal of Contemporary Hospitality Management, 10, $198-202$. http://dx.doi.org/10.1108/09596119810227811

[38] Merisavo, M. and Raulas, M. (2004) The Impact of E-Mail Marketing on Brand Loyalty. Journal of Product and Brand Management, 13, 498-505. http://dx.doi.org/10.1108/10610420410568435

[39] Hansotia, B. (2002) Gearing up for CRM: Antecedents to Successful Implementation. Journal of Database Marketing, 10, 121-132. http://dx.doi.org/10.1057/palgrave.jdm.3240103

[40] Reichheld, F. and Shefter, P. (2000) E-Loyalty: Your Secret Weapon on the Web. Harvard Business Review, 78, 105114.

[41] Sigala, M. (2003) The Information and Communication Technologies Productivity Impact on the UK Hotel Sector. International Journal of Contemporary Hospitality Management, 23, 1224-1245.

[42] Martin, L.M. (2004) E-Innovation: Internet Impacts on Small UK Hospitality Firms. International Journal of Contemporary Hospitality Management, 16, 82-90. http://dx.doi.org/10.1108/09596110410519964

[43] Collins, C., Buhalis, D. and Peters, M. (2003) Enhancing SMTEs Business Performance through the Internet and ELearning Platforms. Education and Training, 45, 483-494. http://dx.doi.org/10.1108/00400910310508874

[44] Simpson, M.C. (2008) Community Benefit Tourism Initiatives-A Conceptual Oxymoron? Tourism Management, 29, 1-18. http://dx.doi.org/10.1016/j.tourman.2007.06.005 
[45] Newell, F. (2000) Loyalty.com: Customer Relationship Management in the New Era of Internet Marketing. McGraw Hill Professional, New York.

[46] Murphy, J.E., Forrest, J., Wotring, C.E. and Brymer, R.A. (2006) Hotel Management and Marketing on the Internet. Cornell Hotel and Restaurant Administration Quarterly, 37, 70-82. http://dx.doi.org/10.1177/001088049603700322

[47] Kim, M.J., Chung, N. and Lee, C.K. (2011) The Effect of Perceived Trust on Electronic Commerce: Shopping Online for Tourism Products and Services in South Korea. Tourism Management, 32, 256-265. http://dx.doi.org/10.1016/j.tourman.2010.01.011

[48] Sawabini, S. (2001) EDI and the Internet: Can Two Generations of E-Commerce Coexist. Journal of Business Strategy, 22, 41-43. http://dx.doi.org/10.1108/eb040143

[49] Ngai, E.W.T. and Gunasekaran, A. (2004) Implementation of EDI in Hong Kong: An Empirical Analysis. Industrial Management \& Data Systems, 104, 88-100. http://dx.doi.org/10.1108/02635570410514124

[50] Leonard, L.N.K. and Clemons Davis, C.C. (2006) Supply Chain Replenishment: Before-and-after EDI Implementation. Supply Chain Management: An International Journal, 11, 225-232. http://dx.doi.org/10.1108/13598540610662121

[51] Lo, A.S., Stalcup, L.D. and Lee, A. (2010) Customer Relationship Management for Hotels in Hong Kong. International Journal of Contemporary Hospitality Management, 22, 139-159. http://dx.doi.org/10.1108/09596111011018151

[52] Osarenkhoe, A. and Bennani, A.Z. (2011) Scandic Hotel Chain in the Baltic-A Case of Strategic Marketing. Emerald Emerging Markets Case Studies, Teaching Case in Marketing Management.

[53] Pantano, E. and Naccarato, G. (2010) Entertainment in Retailing: The Influences of Advanced Technologies. Journal of Retailing and Consumer Services, 17, 200-204. http://dx.doi.org/10.1016/j.jretconser.2010.03.010

[54] Van Hoof, H., Hubert, B., Hein, F., Ruys, M. and Combrink, C. (1999) The Use of the Internet in the Queensland Accommodation Industry. Australian Journal of Hospitality Management, 6, 11-24.

[55] Zettelmeyer, F. (2000) Expanding to the Internet: Pricing and Communications Strategies When Firms Compete on Multiple Channels. Journal of Marketing Research, 37, 292-308. http://dx.doi.org/10.1509/jmkr.37.3.292.18777

[56] Alba, J., Lynch, J., Weitz, B., Janiszewski, C., Lutz, R., Sawyer, A. and Wood, S. (1997) Interactive Home Shopping: Consumer, Retailer, and Manufacturer Incentives to Participate in Electronic Market Place. Journal of Marketing, 61, 38-53. http://dx.doi.org/10.2307/1251788

[57] Hoffman, D. and Novak, T. (1996) Marketing in Hypermedia Computer-Mediated Environments: Conceptual Foundations. Journal of Marketing, 60, 50-68. http://dx.doi.org/10.2307/1251841

[58] Piercy, N.F. (1995) Customer Satisfaction and the Internal Market: Marketing Our Customers to Our Employees. Journal of Marketing Practice: Applied Marketing Science, 1, 22-44. http://dx.doi.org/10.1108/EUM0000000003878

[59] Siguaw, J.A., Enz, C.A. and Namiasivayam, K. (2000) Adoption of Information Technology in US Hotels: Strategically Driven Objectives. Journal of Travel Research, 39, 192-201. http://dx.doi.org/10.1177/004728750003900209

[60] Kim, H.Y. and Kim, Y.K. (2008) Shopping Enjoyment and Store Shopping Modes: The Moderating Influence of Chronic Time Pressure. Journal of Retailing and Consumer Services, 15, 410-419. http://dx.doi.org/10.1016/j.jretconser.2007.10.003

[61] Van Hoof, H. (1998) The Use of the Internet in the US Lodging Industry. Florida International University Hospitality Review, 16, 77-90.

[62] Olsen, M.D. (1996) Into the New Millennium: A White Paper on the Global Hospitality Industry. International Hotel Association, Paris.

[63] Cooper, C., Scott, N. and Baggio, R. (2009) Network Position and Perceptions of Destination Stakeholder Importance. Anatolia: An International Journal of Tourism Research, 20, 33-45.

[64] Chen, M.H. (2010) Interactions between Business Conditions and Financial Performance of Tourism Firms: Evidence from China and Taiwan. Tourism Management, 28, 188-203. http://dx.doi.org/10.1016/j.tourman.2005.11.012

[65] Pechlaner, H., Rienzner, H., Matzler, K. and Osti, L. (2002) Response Attitudes and Behavior of Hotel Industry to Electronic Info Requests. In: Wöber, K.W., Frew, A.J. and Hitz, M., Eds., Information and Communication Technologies in Tourism 2002, Springer Computer Science, Springer, Vienna, New York, 177-186.

[66] Nyheim, P., McFadden, F. and Connolly, D. (2004) Technology Strategies for the Hospitality Industry. Prentice-Hall, Upper Saddle River.

[67] Donaldson, B. and Toole, T.O. ( 2009) Strategic Market Relationship. John Wiley \& Sons, Ltd., Chichester.

[68] Cilan, C.A., Balaban, E., Coskun, E. and Sharma, D. (2007) An Exploratory Study of Information Technology Utilization and Its Influence on Business Performance of Upscale Hotel Industry in Turkey. International Journal of Business Strategy, 7, 20-43. 
Scientific Research Publishing (SCIRP) is one of the largest Open Access journal publishers. It is currently publishing more than 200 open access, online, peer-reviewed journals covering a wide range of academic disciplines. SCIRP serves the worldwide academic communities and contributes to the progress and application of science with its publication.

Other selected journals from SCIRP are listed as below. Submit your manuscript to us via either submit@scirp.org or Online Submission Portal.
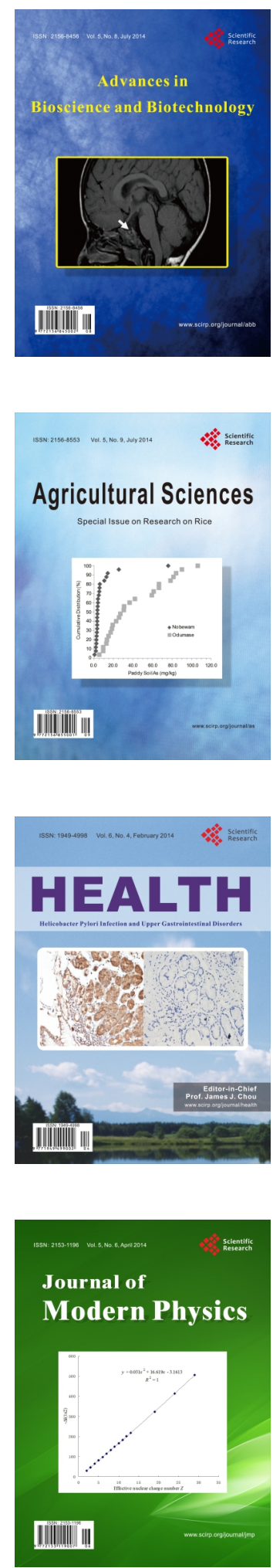
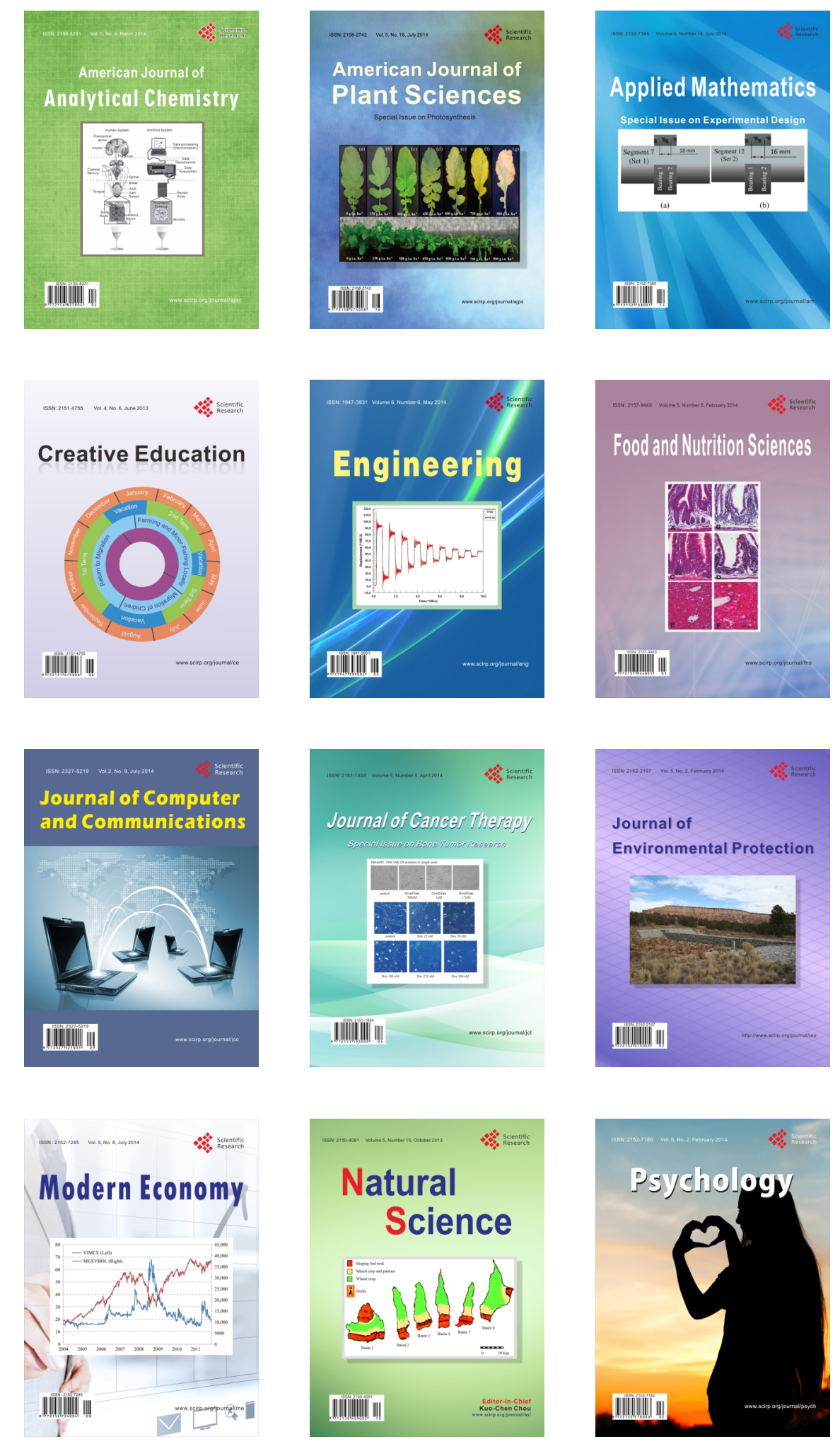